Lucyna Kopciewicz

https://doi.org/10.26881/pwe.2020.50.06

ORCID: 0000-0003-0888-7665

Uniwersytet Gdański

lucyna.kopciewicz@ug.edu.pl

\title{
Czy pojawienie się technologii informacyjno-komunikacyjnych w klasie szkolnej oznacza zmianę praktyk nauczania i uczenia się?
}

\section{Summary \\ Does the appearance of digital technologies in the classroom mean a change within teaching and learning practices?}

Research on technology integration in school classrooms convinces that digital technologies are closely related to the discourse of educational change. What really changes when digital technology is used in the classroom? This is the driving question for the present study. This research contributes knowledge on learning and teaching practices in 19 early education classrooms observed over two school semesters. The design of teaching and learning with tablet technology was explored using the didactical design framework. This perspective focuses on both teachers' practices and students' learning activities in the classroom and how tablet technology is integrated into teaching and learning practices. Although the research project was performed on a small scale, it can be defined as one that documents the changes to learning and teaching practices happening in the traditional educational culture of the schools under analysis. These changes were identified through the data collected by means of structured classroom observation (283 teaching hours) and interviews with classroom teachers. The analysis resulted in three distinct sets of emergent teaching and learning practices and a series of conflicts and tensions teachers experience in their everyday tablet-mediated teaching practices.

Keywords: early education, teacher, information and communication technologies, teaching and learning practices, student

Słowa kluczowe: wczesna edukacja, nauczyciel, technologie informacyjno-komunikacyjne, praktyki nauczania i uczenia się, uczeń

Pojawienie się technologii informacyjno-komunikacyjnych w szkole jest uznawane za oczywisty krok modernizacyjny ${ }^{1}$ (Pyżalski 2017; Wrońska 2017). W badaniach nad integracją technologii w klasach szkolnych wskazuje się, że pojawieniu się narzędzi cyfrowych towarzyszą zarówno oczekiwania edukacyjnej zmiany w zakresie sposobów przekazu wiedzy, uczenia się,

\footnotetext{
1 Artykuł powstał w ramach projektu badawczego, prowadzonego w Instytucie Pedagogiki w Uniwersytecie Gdańskim, finansowanego przez Narodowe Centrum Nauki 2015/19/B/HS6/02218 „Uczenie się wspomagane technologiami mobilnymi w szkołach pomorskich. Krytyczne pytania o rozwój »kompetencji XXI wieku« oraz genderową inkluzję w szkolnych modelach BYOD/BYOT oraz OPD”.
} 
nabywania nowych umiejętności, jak i zasadnicze trudności związane z wkomponowaniem narzędzi informatycznych w codzienne praktyki nauczania (Säljö 2010; Dylak 2013).

Celem tego artykułu jest analiza projektowanych przez nauczycielki praktyk nauczania i uczenia się w związku z pojawieniem się tabletów w szkolnych klasach. Na użytek badań przyjęto ramę teoretyczną zdefiniowaną na gruncie cyfrowego projektowania dydaktycznego (Jahnke, Kumar 2014; Jahnke i in. 2017). Badaniu podlegały komponenty zawarte w Schemacie kodowania w tabeli 1 (kategorie A-F). Kolejnym źródłem teoretycznym jest model SAMR, który pozwolił opisać zróżnicowane sposoby integracji technologii w procesy nauczania i uczenia się w klasie szkolnej (Puentedura 2014). Zidentyfikowane poziomy nazwano następująco:

- substytucja: technologie są wykorzystywane do wykonywania tych samych zadań, które można wykonać bez ich udziału (zastępują tradycyjne);

- rozszerzenie: na tym poziomie technologia jest wykorzystana jako skuteczne narzędzie rozwiązywania podstawowych problemów, oferuje ulepszenie wykonania zadań oraz natychmiastową informację zwrotną o poziomie jego wykonania;

- modyfikacja: to pierwszy poziom, w którym odchodzi się od tradycyjnego modelu nauczania, a technologia zaczyna odgrywać znaczącą rolę dydaktyczną; jest ona niezbędnym narzędziem do wykonania zadania;

- redefinicja: nowe narzędzia są niezbędne do wykonania złożonych zadań, choć kluczowe są umiejętności i postawy uczniów: innowacyjność, współpraca, skuteczna komunikacja pomiędzy członkami zespołu.

Dodatkowym komponentem badania była analiza refleksji, dylematów i ocen nauczycielek dotyczących projektowanych przez nie praktyk nauczania i uczenia się w szkole z tabletami.

Tabela 1. Schemat kodowania

\begin{tabular}{|c|c|}
\hline Kategoria & Opis przyjętego schematu kodowania \\
\hline $\begin{array}{l}\text { A. Typ przyjętych } \\
\text { celów } \\
\text { kształcenia }\end{array}$ & $\begin{array}{l}\text { 1. niejasne, realizacja tematu zajęć } \\
\text { 2. przekaz wiedzy, utrwalanie wiedzy/umiejętności } \\
\text { 3. poszukiwanie informacji/ rozwiązanie problemu w ramach narzuconych } \\
\text { przez nauczyciela } \\
\text { 4. poszukiwanie informacji/ rozwiązanie problemu przez przetwarzanie } \\
\text { rozwiązań zaproponowanych przez nauczyciela } \\
\text { 5. samodzielne wytwarzanie wiedzy/ rozwiązanie problemu w nowej } \\
\text { formie }\end{array}$ \\
\hline $\begin{array}{l}\text { B. Typ } \\
\text { realizowanych } \\
\text { działań uczenia } \\
\text { się }\end{array}$ & $\begin{array}{l}\text { 1. oglądanie materiałów poglądowych (prezentacji przygotowanej przez } \\
\text { nauczyciela) } \\
\text { 2. indywidualne/grupowe ćwiczenie, utrwalanie umiejętności } \\
\text { 3. aktywność indywidualna/grupowa, polegająca na stosowaniu rozwiązań } \\
\text { pod kontrolą nauczyciela } \\
\text { 4. aktywność grupowa, polegająca na przetwarzaniu wiedzy i rozwiązań } \\
\text { problemu sugerowanych przez nauczyciela } \\
\text { 5. aktywność grupowa polegająca na wytwarzaniu wiedzy/ tworzeniu } \\
\text { rozwiązań metodą prób i błędów (zachęcanie do eksperymentowania) }\end{array}$ \\
\hline
\end{tabular}


Tabela 1. cd.

\begin{tabular}{|c|c|}
\hline Kategoria & Opis przyjętego schematu kodowania \\
\hline $\begin{array}{l}\text { C. Wykorzystanie } \\
\text { zasobów } \\
\text { dydaktycznych }\end{array}$ & $\begin{array}{l}\text { 1. dominacja „podręcznika”, tablet/robot wykorzystywany marginalnie } \\
\text { 2. dominacja „podręcznika”, aplikacje ściśle podporządkowane materiałowi } \\
\text { podręcznikowemu } \\
\text { 3. przełamywanie monopolu ,podręcznika” przez wielość i zróżnicowanie } \\
\text { aplikacji } \\
\text { 4. przełamywanie monopolu ,podręcznika” przez aplikacje służące } \\
\text { reorganizacji wiedzy/rozwiązaniu problemu } \\
\text { 5. wykorzystywanie aplikacji służących wytwarzaniu wiedzy/ } \\
\text { rozwiązywaniu problemów oraz równoważenie wiedzy } \\
\text { „podręcznikowej” }\end{array}$ \\
\hline D. Rola ucznia & $\begin{array}{l}\text { 1. odbiorca gotowych treści kształcenia } \\
\text { 2. cierpliwy wykonawca - ćwiczenie i utrwalanie dostarczanej wiedzy } \\
\text { i umiejętności (zapamiętanie) } \\
\text { 3. kopista - odtwórca treści kształcenia/ zastosowań z marginesem } \\
\text { swobody } \\
\text { 4. przetwórca wiedzy/rozwiązań z większym marginesem swobody - } \\
\text { przekształcanie i grupowe negocjowanie rozwiązań } \\
\text { 5. badacz i negocjator - grupowe wytwarzanie wiedzy/ poszukiwanie } \\
\text { rozwiązań w uczącym się zespole }\end{array}$ \\
\hline $\begin{array}{l}\text { E. Rola } \\
\text { nauczyciela }\end{array}$ & $\begin{array}{l}\text { 1. ekspert, kontroluje krótki czas aktywności z tabletem/robotem przez } \\
\text { dodatkowe procedury } \\
\text { 2. ekspert, limituje czas korzystania z tabletów/robotów i kontroluje } \\
\text { prawidłowość użycia aplikacji, w razie potrzeby wspiera w zakresie } \\
\text { technicznym } \\
\text { 3. ekspert-kontroler oraz facylitator, wspiera zaangażowanie uczniów, } \\
\text { pomaga uczniom w zakresie merytorycznym i technicznym, silna } \\
\text { kontrola procesu uczenia się } \\
\text { 4. konsultant, monitoruje kolejne etapy pracy grupowej, udziela informacji } \\
\text { zwrotnych } \\
\text { 5. towarzysz, obserwator samodzielnych poczynań uczniowskich }\end{array}$ \\
\hline $\begin{array}{l}\text { F. Ocenianie } \\
\text { i informacje } \\
\text { zwrotne }\end{array}$ & $\begin{array}{l}\text { 1. brak informacji zwrotnej, ocenianie nie występuje } \\
\text { 2. komentarz do zajęć, rodzaj ogólnego podsumowania } \\
\text { 3. ocena skierowana do jednostki lub grupy dotycząca efektu pracy } \\
\text { 4. ocena i informacja zwrotna podczas poszczególnych etapów pracy } \\
\text { indywidualnej lub grupowej oraz po zakończeniu pracy } \\
\text { 5. kryteria oceniania ogłoszone na początku zajęć, informacja zwrotna na } \\
\text { kolejnych etapach pracy, ocena po zakończeniu pracy, elementy oceny } \\
\text { doradczej }\end{array}$ \\
\hline $\begin{array}{l}\text { G. Cele nauczania } \\
\text { w związku } \\
\text { z rolą } \\
\text { technologii }\end{array}$ & $\begin{array}{l}\text { 1. uatrakcyjnienie transmisji wiedzy } \\
\text { 2. substytucja - usprawnienie } \\
\text { 3. poszerzenie - ulepszenie } \\
\text { 4. modyfikacja - zmiana } \\
\text { 5. redefinicja - transformacja }\end{array}$ \\
\hline
\end{tabular}

Źródło: badania własne. 


\section{Informacje o projekcie badawczym}

Badania empiryczne zostały przeprowadzone $\mathrm{w}$ siedmiu pomorskich szkołach podstawowych. Uczestniczyło w nich 19 nauczycielek wczesnej edukacji i 19 zespołów klasowych. Zebrany materiał badawczy jest efektem 15 skategoryzowanych obserwacji w każdej klasie szkolnej (w wypadku jednej ze szkół - 14 obserwacji), przeprowadzonych w ciągu dwóch semestrów nauki (razem 282 godziny lekcyjne ${ }^{2}$ obserwacji w latach 2016-2018). W ciągu dwóch semestrów obserwowano te same zespoły uczniowskie i te same nauczycielki, co pozwoliło zachować ciągłość i udokumentować ewentualne zmiany w sposobach edukacyjnego użycia tabletów w dłuższej perspektywie czasowej. Obserwacje były dokonywane w szerszym zespole. Pod koniec każdego okresu obserwacyjnego przeprowadzono wywiady z nauczycielkami, których celem było dotarcie do znaczeń przypisywanych przez nauczycielki technologiom cyfrowym i własnym praktykom oraz poznanie ich odczuć i ocen związanych z pracą z tabletami.

\section{Operacjonalizacja przyjętych modeli teoretycznych}

Przyjmując za punkt wyjścia teorię cyfrowego projektowania dydaktycznego oraz model SAMR, stworzono narzędzie do analizy obserwowanych lekcji (tab. 1). Pojawiły się w nim nazwy głównych kategorii (A-G). Następnie, wykorzystując wiedzę na temat etapów integracji technologii w klasie szkolnej, zostały przypisane wartości (na skali 1-5) oznaczające rozłączne zakresy działań nauczycieli, uczniów oraz sposobów wykorzystania technologii na lekcjach. Wartości najniższe (1 i 2 ) odpowiadają transmisyjnej logice szkoły, z koncentracją na przekazie „zamkniętej” wiedzy, podręczniku i czynnościach zapamiętywania (Klus-Stańska 2011, 2012). W tych kontekstach technologia jest wyraźnie wtłoczona w porządek orientacji transmisyjnej. Wartość 3 odnosi się do prób przełamania transmisyjnej logiki szkoły w analizowanych zakresach działań, choć jednocześnie jest nacechowana dużą nauczycielską presją i wzmożoną kontrolą. Wartości 4 i 5 odnoszą się do sytuacji uczenia się poza ramą transmisyjnej logiki - są to próby oddolnego konstruowania modelu progresywnego uczenia się, w którym znaczącą funkcję pełni technologia.

\section{Procedura kodowania}

Analiza przebiegła z zastosowaniem następujących kroków:

- zastosowanie schematu kodowania do każdej obserwowanej lekcji (wartość poszczególnych kodów była efektem dyskusji zespołu trzech obserwatorów zaangażowanych w realizację badań);

- wyznaczenie mediany w poszczególnych kategoriach A-G;

2 Obserwacja dotyczyła jednostki lekcyjnej, czyli 45 minut zajęć dydaktycznych. 
- umieszczenie wartości mediany w poszczególnych kategoriach na wykresie, co umożliwia ocenę obserwowanych praktyk z punktu widzenia zmiany transmisyjnej logiki szkoły (Jahnke, Kumar 2014).

Po lekturze treści wywiadów z nauczycielkami przystąpiono do procedury kodowania, określając sprzeczności, dylematy i rozterki, z którymi musiały się one mierzyć na różnych etapach projektowania dydaktycznego. Porównanie dylematów nauczycielskich i odniesienie ich do wykresów wyłaniających się z praktyk nauczania i uczenia się pozwoliło na powiązanie obserwowalnych praktyk nauczania i uczenia się oraz znaczeń nadawanych przez nauczycielki technologiom i własnym działaniom.

\section{Wyniki badań}

W analizowanym materiale badawczym zostały zidentyfikowane trzy wyraźne schematy - układy praktyk projektowania dydaktycznego: postęp, niepewność/napięcie oraz regres. Warto zaznaczyć, że biorące udział w badaniach nauczycielki miały różny staż pracy w zawodzie (3-13 lat pracy zawodowej), ale zbliżone - niewielkie - doświadczenie w zakresie wykorzystania technologii na zajęciach szkolnych (od pół do roku szkolnego). Zatem ich kompetencje w zakresie projektowania dydaktycznego wciąż się kształtują.

\section{Schemat pierwszy: postęp}

Wyraźną zmianę praktyk nauczania w związku z pojawieniem się technologii cyfrowych w ciągu roku szkolnego zaobserwowano w przypadku sześciu nauczycielek. Technologia stała się dla nich okazją do rewizji transmisyjnych sposobów pracy w klasie, próbowania nowych rozwiązań: większej niezależności uczniowskiej, pracy grupowej i projektowej, różnicowania zadań. Nauczycielki te w ciągu rocznych obserwacji konsekwentnie podążały drogą zmian, starając się ograniczyć praktyki nauczania transmisyjnego. W zbiorczej tabeli 2 zawarto mediany w poszczególnych kategoriach działań w pierwszym i drugim semestrze prowadzonych obserwacji. W tabeli 3 przedstawiono mediany w poszczególnych kategoriach obserwowanych działań w semestrze II, natomiast w rysunkach 1, 2 zaprezentowano wyłaniające się praktyki nauczania i uczenia się.

Tabela 2. Mediana w poszczególnych kategoriach obserwowanych działań

\begin{tabular}{|c|c|c|c|c|c|c|c|c|}
\hline \multirow{2}{*}{ Nauczycielka } & \multirow{2}{*}{$\begin{array}{c}\text { Liczba } \\
\text { obserwacji }\end{array}$} & \multicolumn{7}{|c|}{ Mediana w poszczególnych kategoriach } \\
\cline { 3 - 9 } & & A & B & C & D & E & F & G \\
\hline N1 & 7 & 2 & 2 & 3 & 2 & 3 & 2 & 3 \\
\hline N2 & 7 & 1 & 2 & 3 & 2 & 2 & 2 & 3 \\
\hline N3 & 7 & 2 & 2 & 3 & 3 & 3 & 3 & 3 \\
\hline N4 & 8 & 1 & 1 & 1 & 1 & 1 & 1 & 1 \\
\hline N5 & 8 & 2 & 1 & 2 & 2 & 2 & 1 & 2 \\
\hline N6 & 8 & 2 & 2 & 2 & 2 & 2 & 2 & 2 \\
\hline
\end{tabular}

Źródło: opracowanie własne. 

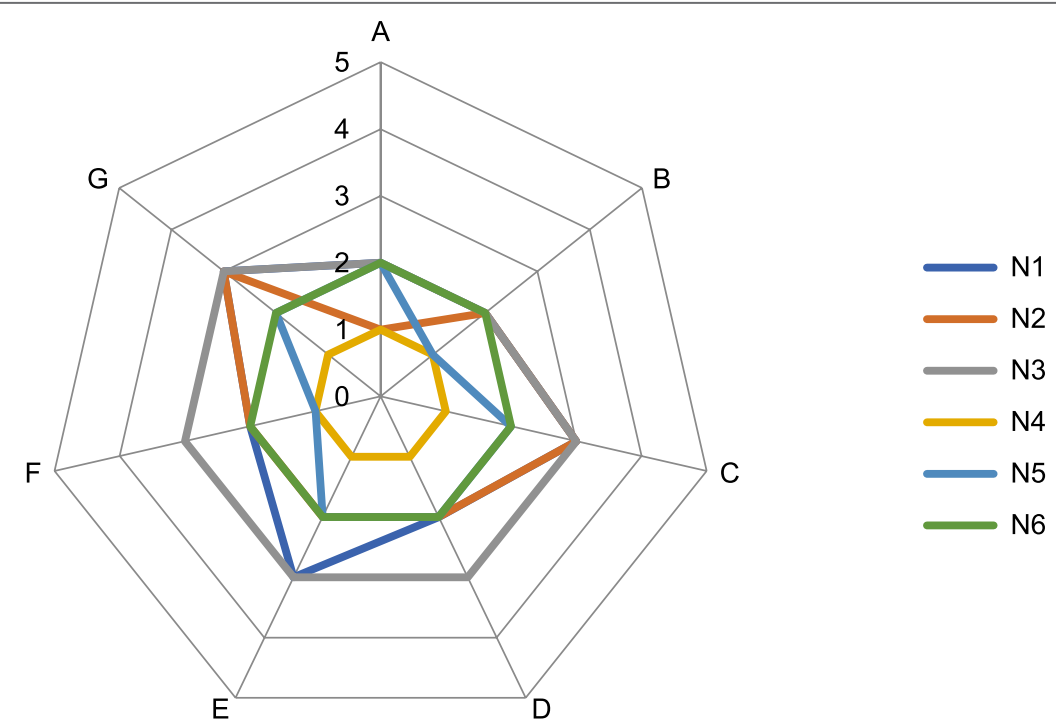

Rysunek 1. Wyłaniające się praktyki nauczania i uczenia się - postęp

Źródło: opracowanie własne.

Tabela 3. Mediana w poszczególnych kategoriach obserwowanych działań w semestrze II

\begin{tabular}{|c|c|c|c|c|c|c|c|c|}
\hline \multirow{2}{*}{ Nauczycielka } & \multirow{2}{*}{$\begin{array}{c}\text { Liczba } \\
\text { obserwacji }\end{array}$} & \multicolumn{7}{|c|}{ Mediana w poszczególnych kategoriach } \\
\cline { 3 - 9 } & & A & B & C & D & E & F & G \\
\hline N1 & 7 & 3 & 3 & 3 & 3 & 3 & 3 & 3 \\
\hline N2 & 7 & 3 & 3 & 4 & 4 & 4 & 4 & 4 \\
\hline N3 & 7 & 3 & 4 & 5 & 3 & 4 & 3 & 5 \\
\hline N4 & 7 & 3 & 4 & 3 & 4 & 3 & 4 & 4 \\
\hline N5 & 7 & 3 & 4 & 4 & 4 & 4 & 4 & 4 \\
\hline N6 & 7 & 4 & 4 & 4 & 4 & 4 & 4 & 4 \\
\hline
\end{tabular}

Źródło: opracowanie własne.

Wyniki uzyskane przez poszczególne nauczycielki różnią się w obu semestrach. W pierwszym okresie obserwacji nauczycielki hołdowały nauczaniu transmisyjnemu (wartości 1 i 2), próbując dobudować do tradycyjnych praktyk elementy innowacyjne (wartość 3). Technologie cyfrowe stały się jednak sposobnością do głębszego przeorganizowania dotychczasowych praktyk (wartości 4 i 5). 

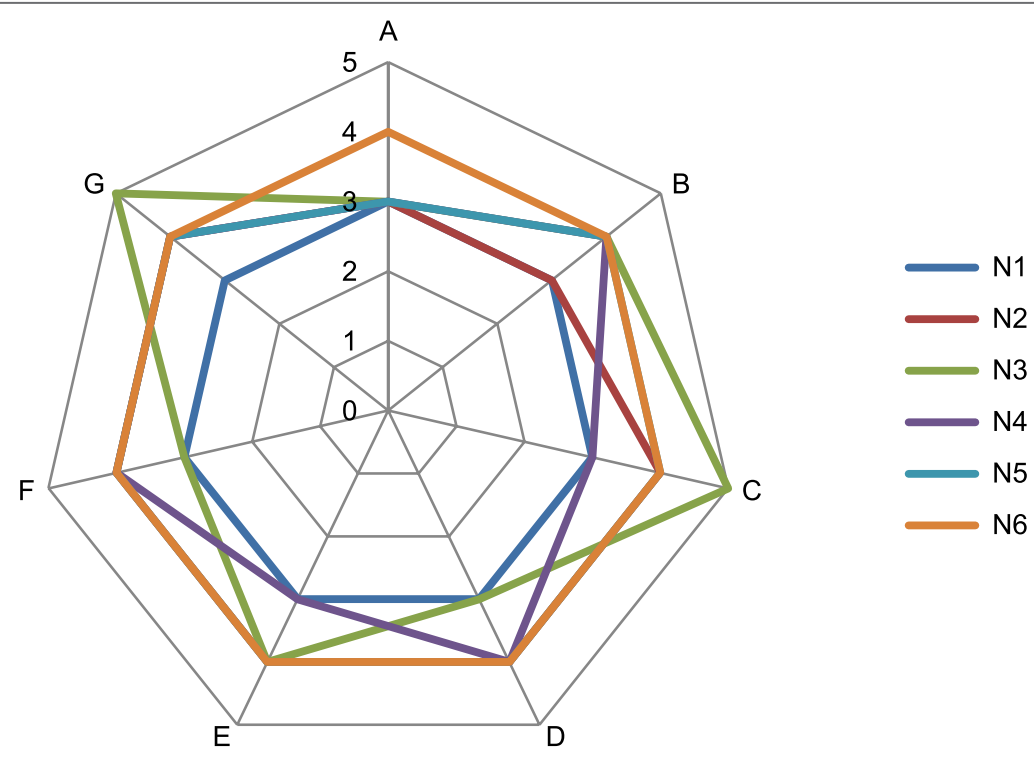

Rysunek 2. Wyłaniające się praktyki nauczania i uczenia się w związku z integracją technologii w semestrze II

Źródło: opracowanie własne.

A. Typ przyjętych celów kształcenia. W pierwszym okresie obserwacji nauczycielki rzadko informowały o celu proponowanych zajęć. W kolejnym semestrze ten wymiar ich pracy uległ modyfikacji - uczniowie częściej otrzymywali takie informacje (najważniejszą zmianą jest informowanie o celach użycia tabletów w związku z planowanymi zadaniami czy projektami).

B. Typ realizowanych działań uczenia się. W pierwszym okresie obserwacji nauczycielki wykorzystywały tablety marginalnie i raczej jako uzupełnienie lub uatrakcyjnienie tradycyjnych zadań (zawartych w podręczniku czy zeszycie ćwiczeń): układanie puzzli, korzystanie z aplikacji matematycznych ćwiczących określony typ działań, aplikacji z figurami geometrycznymi czy aplikacji plastycznych. W kolejnym semestrze można było zaobserwować bardziej zróżnicowane wykorzystanie technologii - nie tylko pojedyncze aplikacje, które ćwiczą wybrany zakres umiejętności (utrwalanie słownictwa, gry logiczne itp.), ale też w zespołowych projektach - fotograficznych czy projektowania gier. Tablety były zatem wykorzystywane do realizacji celów, których nie można było osiągnąć w inny sposób - bez technologii.

C. Wykorzystanie zasobów dydaktycznych. W wypadku tego wymiaru również zanotowano odejście od rygorystycznego podporządkowania tabletów podręcznikowi i zaprzestanie wykorzystania tabletów do uatrakcyjniania zaplanowanych ćwiczeń. W drugim semestrze nauczycielki bardziej elastycznie traktowały technologie: czasami jako „roz- 
szerzenie" treści dostępnych w podręcznikach, czasem niezależnie od materiałów tradycyjnych, czasem aplikacje były punktem wyjścia do pracy z podręcznikiem.

D. Rola ucznia. Na początkowych etapach obserwacji projektowane zadania uczennic i uczniów nie wykraczały poza role odbiorców gotowych treści i wykonawców trenujących wybrany zakres sprawności. W drugim semestrze nauczycielki modyfikowały te role, pozostawiając uczniom i uczennicom więcej swobody działania. Nauczycielki podjęły ryzyko stworzenia przestrzeni dla sprawczych działań - uczniowie i uczennice mogli samodzielnie określać sposoby realizacji wybranych zadań (poszczególnych aspektów projektu), współdziałając w grupie i wypracowując rozwiązania.

E. Rola nauczyciela. W pierwszym semestrze nauczycielki rzadko wykraczały poza rolę ekspertów, koncentrowały się na krótkim czasie, w którym dzieci mogły korzystać z tabletów. W ich działaniach widoczna była tendencja do oddzielania działań „analogowych" od cyfrowych (,najpierw zrobimy ćwiczenie, a potem pobawicie się tabletem”). Nadzorowały czas aktywności z tabletem, pilnując, by po zakończonych działaniach tablety znajdowały się poza zasięgiem uczniów. W drugim semestrze praktyki te uległy pewnemu osłabieniu na rzecz większej samodzielności uczniów i uczennic, pozostawienia im otwartej przestrzeni do wzajemnej pomocy i samodzielnych eksploracji. Czas planowanych aktywności z tabletem był bardziej zróżnicowany, obejmował dłuższe sekwencje działań. Poza tym dzieci miały możliwość wyboru drogi realizacji poszczególnych zadań - mogły korzystać z tabletów, ale też używać tradycyjnych narzędzi i materiałów.

F. Ocenianie i informacje zwrotne. Ten wymiar pracy nauczycielek również się zmienił. Nauczycielki dokonywały ogólnego podsumowania, chwaląc poszczególne osoby lub grupy za dobrą pracę i ciekawe pomysły. W drugim semestrze częściej pojawiały się praktyki oceniania konsultacyjnego, zamykającego określony etap działań indywidualnych lub grupowych.

G. Cel użycia technologii na lekcji (istota „zadań technologicznych”). Sposób wykorzystania technologii w pierwszym semestrze obejmował substytucję i rozszerzanie, co odzwierciedla wysiłki podporządkowania nowych narzędzi edukacyjnych dominującym praktykom nauczania (bez ich modyfikacji). Technologia miała tu za zadanie wspomóc i uatrakcyjnić przekaz wiedzy. Natomiast w drugim semestrze dostrzegalna była zmiana praktyk nauczania. Nauczycielki nadal odwoływały się do modelu rozszerzenia, ale też redefinicji i modyfikacji - technologia stała się w nich warunkiem realizacji nowych zadań, które nie byłyby możliwe bez technologii (np. filmów, kolaży fotograficznych, projektów z wykorzystaniem kodów QR, kodowaniem itp.).

$\mathrm{Z}$ analiz treści wywiadów z nauczycielkami wyłoniły się sprzeczności i napięcia, które zdefiniowano jako pierwotne, dotyczyły one bowiem fundamentalnych wątpliwości związanych z nadawaniem się tabletów do realiów polskiej szkoły.

N1: Po pierwszych katastrofach stwierdziłam, że ta zabawka w ogóle się nie nadaje do szkoły, a na pewno nie do polskiej szkoły. Tablety nie chciały mi się ułożyć do zajęć. Potem 
zrozumiałam, że można zrobić inaczej - ułożyć zajęcia do tabletów. Ta zmiana wymaga jednak czasu i przestawienia myślenia o planowaniu lekcji.

Wątpliwości związane w wykorzystaniem technologii na lekcjach pierwotnie były sformułowane „nauczycielocentrycznie” przez pryzmat obciążenia czasowego, braku przewodnictwa, konieczności samotnego zmagania się z materią technologiczną bez pomocy i wsparcia:

N2: Na początku był entuzjazm, a potem już tylko gorzej. Na szkoleniach tablety przedstawiano jako narzędzie, które jest dla nauczyciela pomocą - wszystko ulepszy i ułatwi. Nic takiego się nie stało. Teraz wiem, że jeśli chce się coś sensownego zrobić z tabletem na lekcjach, trzeba naprawdę w to wejść, interesować się, śledzić, samemu szukać, dokształcać się.

N3: Ja myślę, że trzeba być pasjonatem technologii, żeby wykorzystywać tablety na lekcjach. Taki nauczyciel musi mieć świadomość, że zostaje sam w klasie z dwudziestoma tabletami i dziećmi i że sam musi sobie poradzić z planowaniem lekcji, doborem aplikacji czy stworzeniem materiałów. Tu nikt nie pomoże ani nie poda gotowych rozwiązań na tacy. Pamiętam, że na początku bardzo się bałam, i pamiętam, jak wiele czasu zajmowało mi planowanie zajęć. Kilka razy miałam kryzys i chciałam to zarzucić na zasadzie: szkoda mojego czasu i wysiłku. Ale wytrwałam i nie żałuję - lepiej sobie radzę, nabrałam większej wprawy, a najważniejsze, że wiem, co chcę osiągnąć na lekcji i gdzie szukać wskazówek. Tablet jest takim narzędziem, które trzeba dobrze poznać, a potem pomyśleć, jak chcę je wykorzystać na moich lekcjach.

W wypowiedziach nauczycielek bardzo wyraźnie uwidocznia się przejście od rozumienia tabletów jako zabawek i gadżetów do narzędzia pomocnego w realizacji zamierzeń, których nie można byłoby bez niego zrealizować. Można przypuszczać, że w procesie poznawania technologii nauczycielki przekształciły tablet w narzędzie uczenia się, co wymagało od nich wiele wysiłku, samozaparcia i czasu.

N3: Cały czas mam wątpliwości, czy na pewno robię dobry użytek z tego narzędzia. Nie chcę mieć tabletów na lekcji tylko po to, żeby był „bajer”. Jeśli w ogóle mam ich używać, to po to, żeby dzieci mogły zrobić coś, czego nie mogłyby zrobić bez tabletów. Jeśli mogą poradzić sobie same, to tablet nie powinien być używany. Teraz wiem, że tak właśnie powinno być, ale moje początki były bardzo trudne.

N1: Chyba największym problemem był brak świadomości - nie do końca czułam, po co ten tablet, czym on jest, jak go wbudować w zajęcia, jak go używać...

W wypowiedziach uwidocznia się zmiana polegająca na odejściu od „nauczycielocentryzmu" ku umiarkowanemu uczniocentryzmowi - z tego punktu widzenia są podejmowane poszukiwania najlepszych sposobów wykorzystania technologii na zajęciach. 
N3: Najważniejsze dla mnie jest to, że w końcu widzę efekty swojej pracy. Moja klasa naprawdę się uczy i to chętnie. Nie marnujemy czasu, robimy rzeczy, które mają sens odwiedzamy ciekawe miejsca w Internecie, ostatnio robiliśmy gry. U mnie w klasie nie ma nudy, wszyscy pracują, i to ciężko!

N2: Po jakimś czasie zorientowałam się, że przygotowując lekcje, trzeba myśleć o uczniach, a nie o tablecie - jak oni będą pracować, czego się nauczą, co będzie dla nich bardziej wartościowe. Wiem też, że do jakiegoś stopnia muszę być otwarta na ich pomysły, bo to oni realizują zadania, a nie ja. Moja rola nie polega na narzucaniu rozwiązań.

Wydaje się, że początkowe trudności zostały pokonane, a nauczycielki coraz lepiej sobie radzą z projektowaniem nauczania. Dostrzegły edukacyjny potencjał w narzędziach technologicznych i potrafią go spożytkować na lekcji. Można odnieść wrażenie, że nauczycielskie dylematy zostały pomyślnie rozwiązane i zaowocowały nowymi praktykami, korzystnymi z punktu widzenia uczennic i uczniów oraz nauczycielek - obie grupy uczą się nowych rzeczy.

\section{Schemat drugi: niepewność i napięcie}

W wypadku sześciu kolejnych nauczycielek rok szkolny ich działań obfitował w niepewność i napięcia dotyczące praktyk nauczania. Nauczycielki próbowały ocalić praktyki transmisyjnego nauczania i dobudować do nich progresywne elementy. Rok obserwacji wskazuje, że owo napięcie blokuje zmianę (tab. 4, 5, rys. 3, 4).

Tabela 4. Mediana w poszczególnych kategoriach obserwowanych działań w semestrze I

\begin{tabular}{|c|c|c|c|c|c|c|c|c|}
\hline \multirow{2}{*}{ Nauczycielka } & \multirow{2}{*}{$\begin{array}{c}\text { Liczba } \\
\text { obserwacji }\end{array}$} & \multicolumn{7}{|c|}{ Mediana w poszczególnych kategoriach } \\
\cline { 3 - 9 } & 7 & A & B & C & D & E & F & G \\
\hline N1 & 7 & 2 & 2 & 2 & 1 & 1 & 1 & 2 \\
\hline N2 & 7 & 1 & 2 & 2 & 1 & 1 & 1 & 1 \\
\hline N3 & 7 & 1 & 1 & 1 & 1 & 1 & 1 & 1 \\
\hline N4 & 7 & 2 & 1 & 1 & 1 & 1 & 1 & 1 \\
\hline N5 & 7 & 2 & 2 & 2 & 2 & 1 & 1 & 2 \\
\hline N6 & & & & & & & & 1 \\
\hline
\end{tabular}

Źródło: opracowanie własne. 

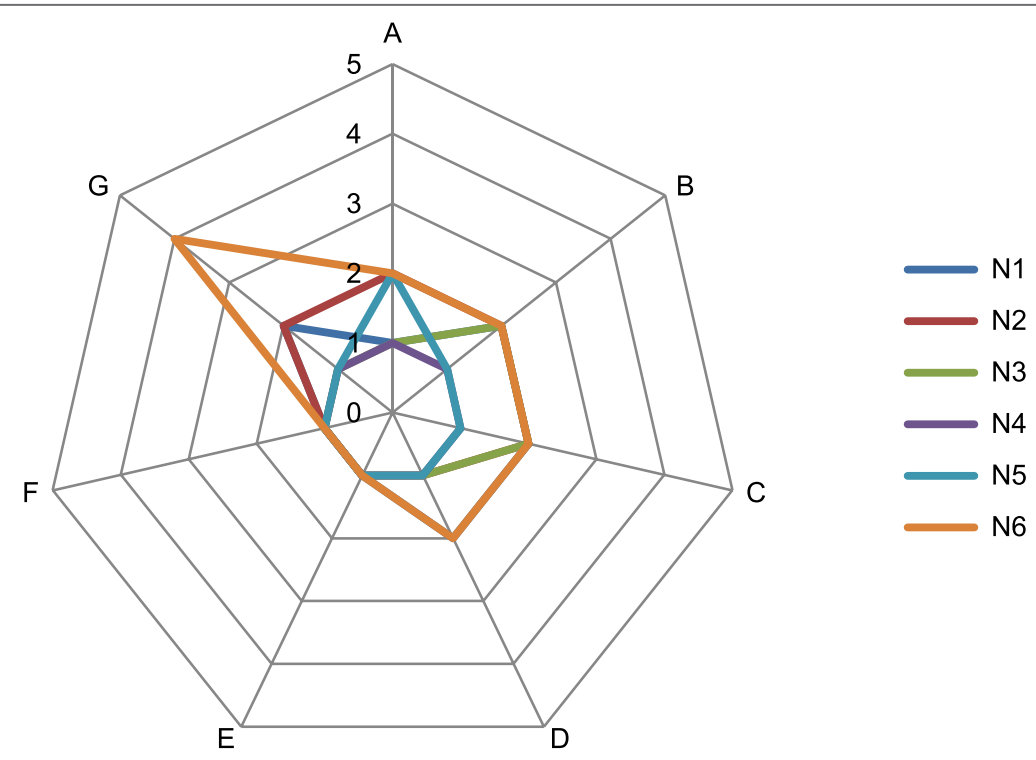

Rysunek 3. Wyłaniające się praktyki nauczania i uczenia się w związku z integracją technologii w semestrze I

Źródło: opracowanie własne.

Tabela 5. Mediana w poszczególnych kategoriach obserwowanych działań w semestrze II

\begin{tabular}{|c|c|c|c|c|c|c|c|c|}
\hline \multirow{2}{*}{ Nauczycielka } & \multirow{2}{*}{$\begin{array}{c}\text { Liczba } \\
\text { obserwacji }\end{array}$} & \multicolumn{7}{|c|}{ Mediana w poszczególnych kategoriach } \\
\cline { 3 - 9 } & & A & B & C & D & E & F & G \\
\hline N1 & 8 & 1 & 1 & 2 & 1 & 1 & 1 & 2 \\
\hline N2 & 8 & 2 & 2 & 2 & 3 & 3 & 2 & 3 \\
\hline N3 & 8 & 2 & 3 & 3 & 3 & 2 & 3 & 3 \\
\hline N4 & 8 & 1 & 2 & 2 & 2 & 2 & 2 & 2 \\
\hline N5 & 8 & 1 & 2 & 2 & 2 & 2 & 2 & 2 \\
\hline N6 & 8 & 2 & 2 & 2 & 3 & 3 & 2 & 2 \\
\hline
\end{tabular}

Źródło: opracowanie własne.

A. Typ przyjętych celów kształcenia. W całym okresie obserwacji nauczycielki najczęściej nie informowały uczniów o celach proponowanych zajęć z wykorzystaniem tabletów. Realizowane cele kształcenia przeważnie obejmowały przekaz wiedzy i ćwiczenie określonych umiejętności. 

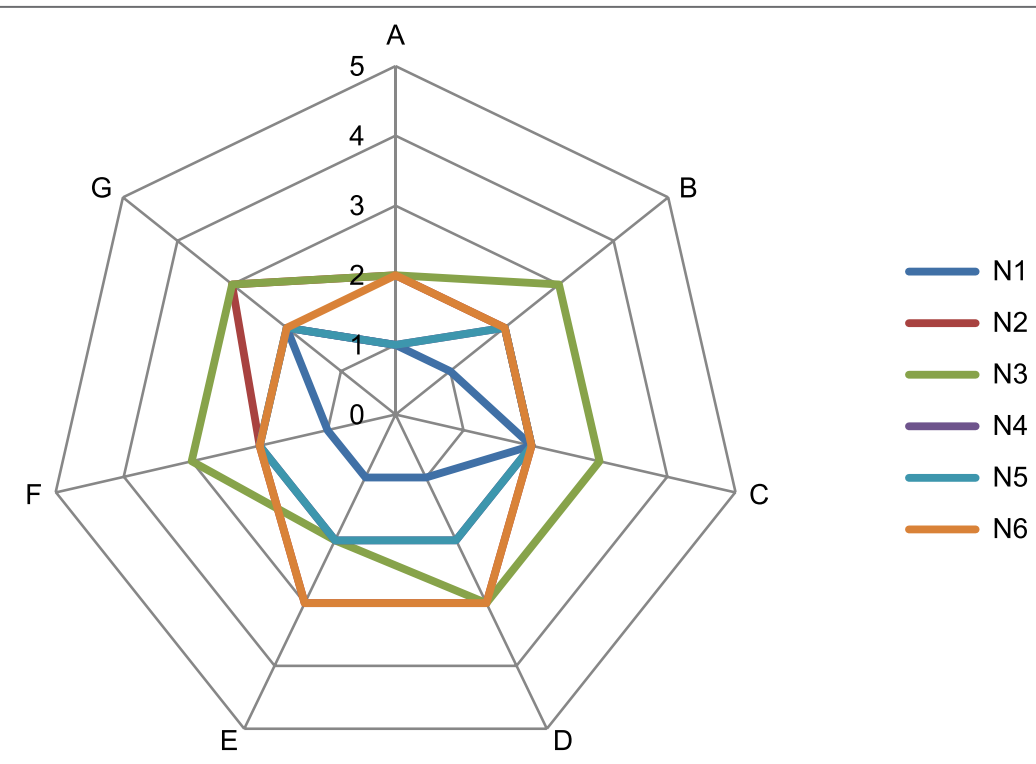

Rysunek 4. Wyłaniające się praktyki nauczania i uczenia się w związku z integracją technologii w semestrze II

Źródło: opracowanie własne.

B. Typ realizowanych działań uczenia się. Tablety były dość często wykorzystywane podczas zajęć, wyłącznie w pracy indywidualnej (nie zaobserwowano żadnych prób pracy grupowej). Były stosowane do ćwiczenia wybranych umiejętności (ćwiczeń zakładających dużą liczbę powtórzeń - utrwalanie i doskonalenie słownictwa w języku angielskim, znajomość liter, ćwiczenie działań matematycznych).

C. Wykorzystanie zasobów dydaktycznych. W analizowanym okresie nauczycielki nie wykroczyły poza podporządkowanie technologii podręcznikowi, który był wiodącym źródłem wiedzy. Technologie cyfrowe były wykorzystywane jedynie wówczas, gdy ich użycie było zgodne z materiałem zawartym w podręczniku (nauczycielki „filtrowały” dostępne aplikacje z punktu widzenia tego kryterium).

D. Rola ucznia. Nauczycielki w okresie obserwacji nie zaprojektowały sytuacji, w których uczniowie i uczennice mieliby okazję wykroczyć poza role pasywne: odbiorców gotowych treści i wykonawców trenujących określone umiejętności lub powielających rozwiązania narzucane przez nauczycielki.

E. Rola nauczyciela. Nauczycielki w zasadzie nie wychodziły poza rolę ekspertów zarządzających aktywnością w klasie szkolnej. Pojawiały się również elementy facylitacji dotyczące kwestii merytorycznych i technicznych. Ich rola była jednak naznaczona kontrolą i dominacją (uzyskane wartości 1-3). Podczas rocznych obserwacji stwierdzono, 
że ich troską była kwestia czasu spędzonego przez uczniów i uczennice na działaniach z wykorzystaniem technologii.

F. Ocenianie i informacje zwrotne. W analizowanym okresie nauczycielki bardzo rzadko udzielały informacji zwrotnych dotyczących wprowadzanych rozwiązań, ich miejsca i roli w uczeniu się. Najczęściej odwoływały się do ogólnego podsumowania zajęć i efektów pracy (zwracały się do uczniów i uczennic jako grupy, choć praca grupowa nigdy nie była podejmowana; zadania były realizowane głównie indywidualnie).

G. Cel użycia technologii na lekcji (istota ,zadań technologicznych”). Sposób wykorzystania technologii $\mathrm{w}$ toku rocznych obserwacji obejmował substytucję i rozszerzanie, co wskazuje na wysiłki podporządkowania nowych narzędzi edukacyjnych transmisyjnym praktykom nauczania. Tablety były wykorzystywane przez nauczycielki głównie jako wsparcie i uatrakcyjnianie przekazu wiedzy i sprawniejszego, szybszego utrwalania umiejętności, co wskazywałoby na realizację ,,programu minimum” w zakresie edukacyjnego potencjału technologii cyfrowych.

Z wypowiedzi nauczycielek wynika, że doświadczane przez nie trudności są konsekwencją pewnego „oszustwa”, którego ofiarą padły podczas szkoleń z zakresu edukacyjnego wykorzystania technologii. Były bowiem przekonane, że otrzymają tablet zawierający wszystkie potrzebne zestawy aplikacji edukacyjnych, a same zostaną jedynie przeszkolone w zakresie ich obsługi. Ich założenia były zatem iluzoryczne - uznały, że tablet jest „magiczną różdżką”, dzięki której uczniowie będą się uczyć lepiej, szybciej i bez pośrednictwa nauczyciela - ten jedynie „odpali” uczniom „,coś edukacyjnego”. Tymczasem rzeczywistość technologiczna okazała się bardziej wymagająca - od nauczycielek oczekuje się umiejętności projektowania zajęć.

N1: Początkowo wszyscy byliśmy bardzo pozytywnie nastawieni, bo panowie z firmy naopowiadali nam jak, tablet ułatwi nam życie. Teraz jest wielkie rozczarowanie: panowie się ulotnili, a my zostaliśmy ze sprzętem, z którym nie do końca wiemy, co robić.

W wypowiedziach pojawił się motyw koleżeńskiego wsparcia jako strategii radzenia sobie z technologią w szkole, które jednak okazało się nietrwałe (słabość kolektywnego uczenia się):

N2: Przez jakiś czas staraliśmy się jakoś wspierać, podpowiadać pomysły, ktoś coś podpatrzył i podpowiedział - i jakoś to wszystko szło. Teraz korzystamy z tych tabletów dla zwykłej przyzwoitości, bo grzech marnować drogi sprzęt. Ale pomysłów już nie mam. Nie chce mi się, nudzi mnie to - czuję się oszukana, czuję, że to nie ma sensu.

Oczekiwanie na edukacyjne cuda przekształciło się w głębokie rozczarowanie - tablety nie „wyczarowują” lekcji. Rozczarowanie z kolei przemieniło się u nich w niechęć. Nauczycielki nie dostrzegły, że nowego narzędzia edukacyjnego można się nauczyć. Zamiast podejmować wysiłek uczenia się, odczuwały bezsilność i złość: 
N3: Tablety to ściema. Jak za dwa lata nas odwiedzicie, to one [tablety] będą porastać grubą warstwą kurzu. Bardzo nieprzemyślana sprawa i pieniądze wyrzucone w błoto.

N1: Daliśmy się omotać panom, którzy nie mają pojęcia o szkole... a my też zachowaliśmy się jak dzieci we mgle...

W wypowiedziach nauczycielek można dostrzec wyłącznie perspektywę nauczycielską - przede wszystkim negatywne emocje kierowane w stronę tabletów. Emocje te są na tyle silne, że nauczycielki nie są w stanie dostrzec zmian na lepsze, które dokonały się w klasie szkolnej dzięki ich pracy. Dylematy nauczycielek związane z technologiami są w całości dyskursem oskarżeń i pretensji. W tej optyce perspektywa potrzeb czy interesów uczniowskich jest całkowicie pominięta i nie pojawia się nawet na marginesie nauczycielskiego namysłu nad obecnością technologii w szkole. Technologia okazuje się kosztownym kłopotem, przedmiotem kpin i narastania barier.

\section{Schemat trzeci: regres}

Bardzo interesująco przedstawia się ostatnia grupa strategii wdrażania technologii cyfrowych. W wypadku siedmiu nauczycielek zauważono wyraźne wycofanie z progresywnych praktyk nauczania (wartość 4) i powrót do praktyk transmisyjnych (wartości 1-2). Tablety stały się zatem okazją do wypróbowania nowych praktyk, kwestionujących transmisyjne sposoby nauczania. Z czasem jednak porzucono je i powrócono w stronę bieguna praktyk transmisyjnych (tab. 6,7 , rys. 5, 6).

Tabela 6. Mediana w poszczególnych kategoriach obserwowanych działań w semestrze I

\begin{tabular}{|c|c|c|c|c|c|c|c|c|}
\hline \multirow{2}{*}{ Nauczycielka } & \multirow{2}{*}{$\begin{array}{c}\text { Liczba } \\
\text { obserwacji }\end{array}$} & \multicolumn{7}{|c|}{ Mediana w poszczególnych kategoriach } \\
\cline { 3 - 9 } & & A & B & C & D & E & F & G \\
\hline N1 & 7 & 2 & 3 & 4 & 3 & 3 & 1 & 4 \\
\hline N2 & 7 & 3 & 3 & 4 & 3 & 3 & 2 & 4 \\
\hline N3 & 7 & 2 & 2 & 3 & 2 & 2 & 1 & 3 \\
\hline N4 & 7 & 3 & 4 & 4 & 3 & 3 & 3 & 3 \\
\hline N5 & 7 & 3 & 3 & 4 & 4 & 4 & 4 & 4 \\
\hline N6 & 7 & 2 & 4 & 4 & 4 & 4 & 3 & 4 \\
\hline N7 & 7 & 2 & 3 & 4 & 4 & 4 & 4 & 4 \\
\hline
\end{tabular}

Źródło: opracowanie własne. 

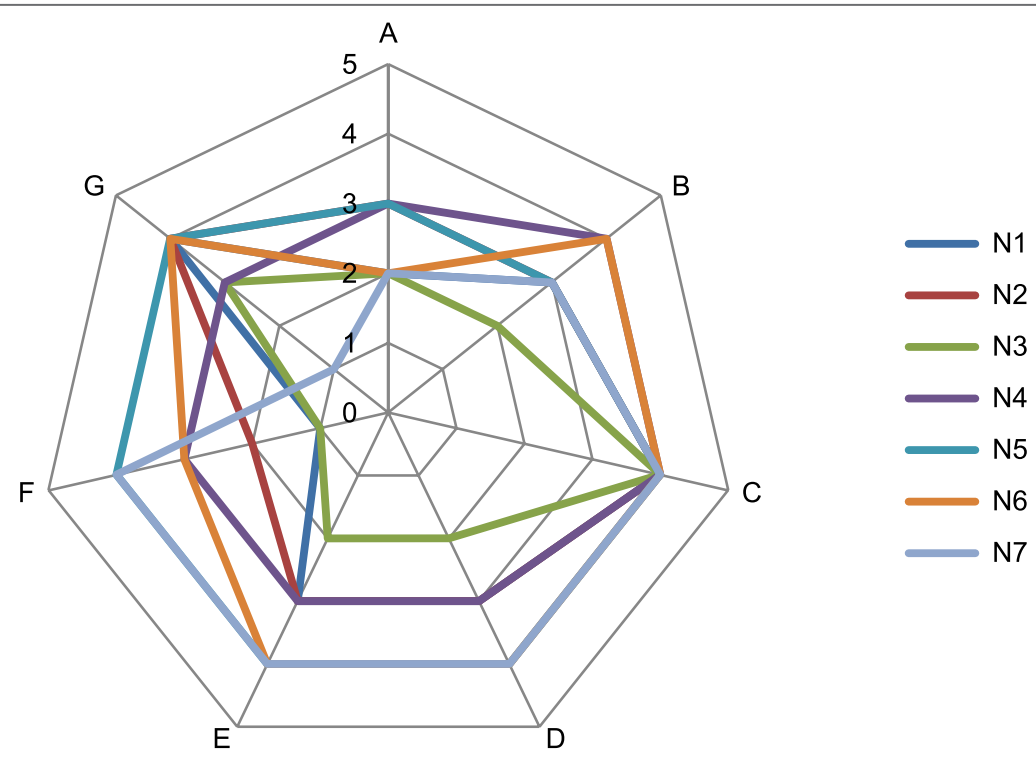

Rysunek 5. Wyłaniające się praktyki nauczania i uczenia się w związku z integracją technologii w semestrze I

Źródło: opracowanie własne.

Tabela 7. Mediana w poszczególnych kategoriach obserwowanych działań w semestrze II

\begin{tabular}{|c|c|c|c|c|c|c|c|c|}
\hline \multirow{2}{*}{ Nauczycielka } & \multirow{2}{*}{$\begin{array}{c}\text { Liczba } \\
\text { obserwacji }\end{array}$} & \multicolumn{7}{|c|}{ Mediana w poszczególnych kategoriach } \\
\cline { 3 - 9 } & & A & B & C & D & E & F & G \\
\hline N1 & 8 & 1 & 1 & 2 & 1 & 1 & 1 & 2 \\
\hline N2 & 8 & 2 & 3 & 3 & 3 & 3 & 2 & 3 \\
\hline N3 & 8 & 2 & 2 & 2 & 2 & 2 & 1 & 2 \\
\hline N4 & 8 & 1 & 2 & 2 & 2 & 2 & 2 & 2 \\
\hline N5 & 8 & 2 & 2 & 3 & 2 & 2 & 2 & 2 \\
\hline N6 & 8 & 2 & 2 & 2 & 2 & 2 & 2 & 1 \\
\hline N7 & 8 & 1 & 2 & 2 & 2 & 1 & 1 & 1 \\
\hline
\end{tabular}

Źródło: opracowanie własne.

A. Typ przyjętych celów kształcenia. O ile w pierwszym okresie obserwacji nauczycielki planowały użycie tabletów w celu utrwalenia wiedzy, ćwiczenia umiejętności oraz samodzielnego rozwiązywania problemów przez uczniów, projektowania (indywidualnie i grupowo), o tyle w kolejnym semestrze realizowały cele, które można by 


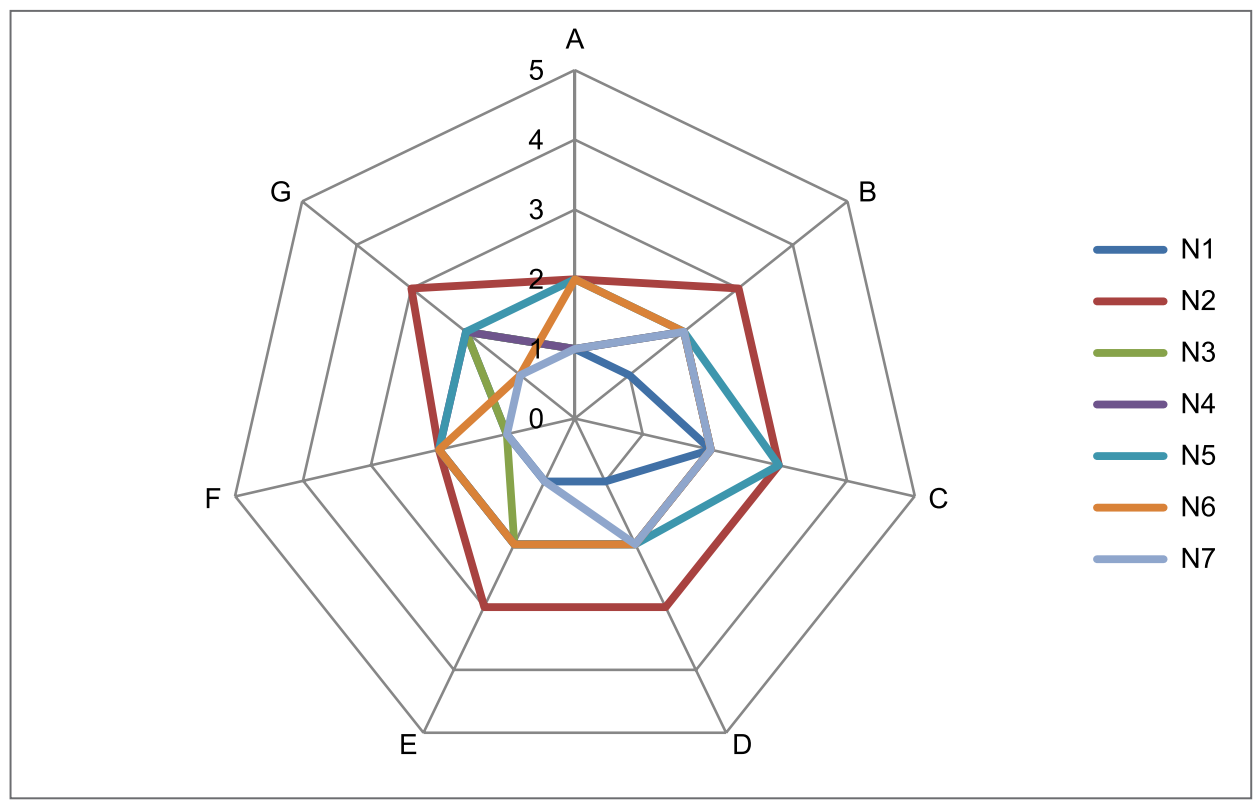

Rysunek 6. Wyłaniające się praktyki nauczania i uczenia się w związku z integracją technologii w semestrze II

Źródło: opracowanie własne.

nazwać minimalnymi - cele zajęć nie były w ogóle komunikowane lub były niejasne, w pozostałych wypadkach obejmowały jedynie utrwalanie wiedzy. Nauczycielki zdecydowanie porzuciły działania nakierowane na samodzielne pozyskiwanie informacji i poszukiwanie rozwiązań przez uczniów.

B. Typ realizowanych działań uczenia się. W pierwszym okresie obserwacji nauczycielki wykorzystywały tablety jako narzędzia grupowej i indywidualnej pracy uczniowskiej - działania te zakładały dość duży stopień uczniowskiej samodzielności lub synergię grupowego uczenia się. W kolejnym okresie prowadzenia obserwacji zostały one zawieszone - uczniowie mogli jedynie zapoznać się z materiałami przygotowanymi przez nauczycielkę (obejrzeć je na ekranie) lub korzystać z aplikacji ćwiczących wybrany zakres umiejętności (np. działania matematyczne).

C. Wykorzystanie zasobów dydaktycznych. Wydaje się, że nauczycielki traktowały tablety jako alternatywne zasoby dydaktyczne, których celem było - przynajmniej w pierwszym okresie obserwacji - zastąpienie podręcznika/zeszytów ćwiczeń. Tablet był stosowany jako niezależna platforma edukacyjna (z zestawem aplikacji, dostępem do informacji i innych źródeł wiedzy). Nauczycielki stopniowo ograniczyły tę rolę do narzędzia podporządkowanego materiałom dostępnym w podręczniku (narzędzie używane wyłącznie w sytuacjach, w których jego wykorzystanie ,zgadzało się” z istotą podręcznikowego przekazu lub treścią ćwiczenia). 
D. Rola ucznia. W całym analizowanym okresie uczniowie i uczennice odgrywali role zakładające odtwórczość i wykonawstwo zadań pod kierunkiem nauczyciela. O ile jednak w pierwszym semestrze nauczycielki zaplanowały dla uczennic i uczniów również spektrum działań niezależnych i sprawczych (samodzielne poszukiwanie informacji, porównywanie pozyskanych informacji itp.), o tyle w kolejnym semestrze margines niezależności w ogóle się nie pojawił.

E. Rola nauczyciela. W pierwszym semestrze nauczycielki często występowały w rolach eksperckich, starając się nadzorować uczniowskie działania. W role eksperckie wpisane były jednak elementy konsultacji, facylitacji i merytorycznego wspierania dzieci. Czas aktywności analogowych i cyfrowych nie był restrykcyjnie wytyczany. Nauczycielki nie pilnowały czasu aktywności z tabletem (czasami dawały uczniom możliwość wyboru drogi poszukiwania informacji - podręcznik lub Internet). W drugim semestrze nauczycielki wycofały się $\mathrm{w} z$ elastycznych i liberalnych praktyk na rzecz rygorystycznego wytyczania limitów czasowych, ścisłego oddzielania czasu aktywności cyfrowej (niedługiej) i tradycyjnej oraz narzucania sposobów realizacji zadań.

F. Ocenianie i informacje zwrotne. Ten wymiar pracy nauczycielek nie uległ zasadniczej zmianie w ciągu rocznego okresu obserwacji. Najczęściej nauczycielki dokonywały ogólnego podsumowania zajęć, często w ogóle nie pojawiał się żaden element odnoszący się do ich oceny (w tym nie przekazywały informacji zwrotnych na temat aktywności cyfrowej uczniów).

G. Cel użycia technologii na lekcji (istota „zadań technologicznych”). Sposób wykorzystania technologii w pierwszym semestrze obejmował rozszerzanie i modyfikację, co świadczyło o ambitnym planie edukacyjnym nauczycielek, wskazywało na ich dojrzałość i kompetencje (wykorzystywały tablety w celu osiągnięcia efektów, które nie byłyby możliwe bez technologii). Niestety w kolejnym semestrze po technologię sięgano głównie w modelu substytucji i rozszerzenia (a więc na niższym poziomie). Być może nauczycielkom zabrakło pomysłów na zajęcia albo planowanie działań z wykorzystaniem bardziej zaawansowanego modelu użycia technologii pochłaniało zbyt wiele nauczycielskiej energii i czasu lub nauczycielki próbowały bardziej związać (podporządkować) nowe narzędzia edukacyjne dominującym praktykom nauczania, uznając wyższość metod tradycyjnych i transmisyjnego modelu nauczania.

W wypowiedziach respondentek ujawniał się zabieg przeciwstawiania podstawy programowej i technologii, co sugeruje, że wybór dokonany pomiędzy nimi musi uszczuplić którą́s z kategorii - albo realizację postawy programowej, albo realizację praktyk uczenia się z wykorzystaniem technologii cyfrowych. Ważną opozycją pojawiającą się w wypowiedziach nauczycielek jest: zabawa - nauka. Tablety są postrzegane jako zabawki, a nie narzędzia edukacyjne, co może wpływać na ich ograniczone włączanie do nauczania.

N1: Z jednej strony jest podstawa programowa, z której nas nikt nie zwolni, z drugiej iPady, które nijak się mają do programu trzeciej klasy. Nikt nie zadbał, żeby przygotować dla nas odpowiednie aplikacje. To tak, jakby nagle wymagać od nauczyciela, żeby pracował 
bez podręcznika i ćwiczeń i sam musiał wszystko od zera zrobić. Dla mnie to jest za duże obciążenie czasowe, choć też muszę powiedzieć uczciwie, że na lekcjach z iPadem zabawa jest świetna.

N2: Ja rozumiem to tak, że w szkole musi być i zabawa, i nauka. Dlatego mamy tablety do zabawy i podręczniki do nauki. Jeśli jeszcze uda się czasem połączyć zabawę z nauką i przemycić ćwiczenie np. tabliczki mnożenia na tablecie, to ja jestem przeszczęśliwa, bo nie dość, że ćwiczymy dużo szybciej i więcej niż na zwykłej karcie pracy, to jeszcze jest to dla dzieci dobra zabawa. No ale ile takich lekcji można zrobić? Wszystko z czasem się nudzi. Ja uważam, że tablety mogą być w szkole, ale na ograniczonej zasadzie. Chyba że ktoś zabrałby się za przygotowanie porządnych materiałów do podstawy programowej. $\mathrm{Na}$ razie bierzemy tablety od czasu do czasu, raczej na zasadzie ciekawostki, przełamania nudy, wprowadzenia elementu zabawy. Problemem dla mnie jest czas. Nie mam czasu na szukanie aplikacji, sprawdzanie, czy wszystko się zgadza...

Wśród innych dylematów i napięć, które ujawniły się w wypowiedziach nauczycielek, odnotowano nadmierne wymagania czasowe, które są związane z koniecznością planowania przez nauczyciela zajęć „od zera”, co w wypadku zajęć z podręcznikiem nie ma miejsca - nauczyciele mogą się odwołać do gotowych scenariuszy zajęć, rozkładu materiału, przygotowanych przez wydawców podręczników i ćwiczeń. Wykorzystanie tabletów wiąże się z brakiem takiego wsparcia, a byłoby ono nauczycielkom bardzo potrzebne. Dylematy i napięcia są sformułowane z perspektywy nauczycielskiej, pomijają potrzeby poznawcze uczniów, ich zainteresowania, trudności itp. Perspektywa uczniowska jest tu reprezentowana marginalnie - grupa uczniowska jest opisywana jako podmioty, które od czasu do czasu powinno się zabawić, zaciekawić i których nie powinno się znudzić.

Trzeba też zauważyć, że edukacyjne wykorzystanie tabletów wymaga od nauczycielek pewnej przebiegłości - „sprzedania” uczniom atrakcyjnej zabawki, która realizuje cele szkolne. Wydaje się, że postrzeganie technologii jako zabawek wymaga od nauczycielek ponadprzeciętnego zaangażowania w projektowanie dydaktyczne, na co nie mają czasu, energii ani pomysłów. Na tym etapie prowadzenia badań dylematy nauczycielskie okazują się siłą wstrzymującą zmianę i odpowiadającą za powrót na utarte ścieżki dydaktyczne nakazują nauczycielkom przedkładanie nauki nad zabawę, podręcznik nad tablet i własnego czasu nad czas ucznia.

\section{Zakończenie}

Celem badań była odpowiedź na pytanie o to, czy pojawienie się nowego narzędzia (tabletów) w przestrzeni szkolnych klas sprzyja edukacyjnej zmianie - czy osłabia transmisyjne praktyki nauczania lub prowadzi do odejścia od nich. Obserwacja zajęć dydaktycznych przekonuje, że nauczycielki starały się podporządkować nowe narzędzia cyfrowe rutynowym transmisyjnym praktykom nauczania - przekazowi i utrwalaniu wiedzy oraz ćwiczeniu zaplanowanych zakresów umiejętności. Praktyki sześciu nauczycielek (schemat 
„niepewność i napięcie”) obejmowały: kontrolowanie aktywności uczniowskiej, narzucanie zasad i ram czasowych działań. Nauczycielki oczekiwały od uczniów sprawnego wykonywania zadań i podporządkowania ustalonym regułom. Materiały szkolne były traktowane jako poważne źródła wiedzy, w przeciwieństwie do tabletów, postrzeganych jako narzędzia zabawowe, rozrywkowe ,uzupełnienie” szkolnych aktywności uczniów. Mimo to owo skuteczne podporządkowanie transmisyjnemu porządkowi szkoły jest dla nich frustrującym doświadczeniem. Zdają sobie sprawę, że technologie cyfrowe można inaczej wykorzystywać w pracy dydaktycznej, ale nie mogą tego zrobić.

Sześciu nauczycielkom udało się w pewnym stopniu zakwestionować praktyki transmisyjne i rozwijać strategie nauczania odwołujące się do większej niezależności poznawczej uczniów, oddające im większe pole do samodzielnych eksploracji. Nauczycielki te działały bardziej jako osoby wspierające i konsultujące uczniowskie pomysły niż wyznaczające zadania i kontrolujące poziom ich wykonania.

Kolejna grupa siedmiu nauczycielek (schemat „regres”) powróciła do transmisyjnych praktyk nauczania i kontroli uczniowskiej aktywności, porzucając dotychczasowe sposoby pracy lekcyjnej - pracę projektową z wykorzystaniem technologii, pracę grupową, samodzielność uczniowską - na rzecz pracy kierowanej i kontrolowanej przez nauczycielki, w której dominują podręczniki, zeszyty ćwiczeń i inne materiały szkolne.

Obserwacja nauczycielskich sposobów pracy z tabletami na lekcjach powadzi do następujących konkluzji: nauczycielki oczekują zmian, ale tylko niektóre z nich mają odwagę je projektować i realizować. Pozostałe obawiają się, że zmiany mogą być zbyt daleko idące - dlatego ich nie podejmują lub się z nich wycofują. Zatem tablet na lekcji jest użyteczny, jeśli niczego nie zmienia w porządku szkolnym - nie jest „,narzędziem zmiany”.

Ważną kwestią są dylematy i napięcia wyrażane przez nauczycielki w związku z projektowaniem praktyk nauczania i uczenia się w środowisku cyfrowym. Warto zwrócić uwagę na sposoby definiowania przez nie współczesnych technologii: czarodziejska różdżka, zabawka i narzędzie edukacyjne, które generują odmienne zakresy możliwych użyć narzędzi cyfrowych i inny zakres projektowanych działań nauczania i uczenia się.

Dylematy nauczycielek dotyczą konfliktu dwóch perspektyw - nauczycielskiej i skoncentrowanej na uczniu. Wydaje się, że nieobecność perspektywy uczniowskiej jest charakterystyczna dla nauczycielek transmisyjnych, które definiują nauczanie szkolne przez pryzmat własnej pracy, potrzeb i czasu. W tej perspektywie tablet okazuje się kłopotem czasochłonnym i pracochłonnym zadaniem, z którym one same muszą sobie radzić. Obecność perspektywy uczniowskiej jest typowa dla nauczycielek progresywnych, które projektują zmiany swojego warsztatu z myślą o potrzebach uczniów i uczennic.

Z pewnością technologie cyfrowe wnoszą w przestrzeń klas szkolnych wartość nowości (odświeżenia, okazji do wypróbowania nowych działań). Wartość ta sama w sobie nie oznacza jednak edukacyjnej zmiany, a jedynie uatrakcyjnienie istniejącego repertuaru działań. 


\section{Literatura}

Dylak S. (2013), Architektura wiedzy w szkole. Warszawa, Difin.

Jahnke I., Kumar S. (2014), Digital Didactical Designs: Teachers 'integration of iPads for learning centered processes. „Journal of Digital Learning in Teacher Education”, 30(3).

Jahnke I., Bergström P., Mårell-Olsson E., Häll L., Kumar S. (2017), Digital Didactical Designs as research framework: iPad integration in Nordic schools. „Computers \& Education”, 113.

Klus-Stańska D. (2011), Dlaczego szkolna kultura dydaktyczna się nie zmienia? „Studia Pedagogiczne", 64.

Klus-Stańska D. (2012), Wiedza, która zniewala: transmisyjne tradycje w szkolnej edukacji. „Forum Oświatowe", 46(1).

Puentedura R. (2014), SAMR Model. http://sites.google.com/a/msad60.org/technology-is-learning/ samr-model, 1.02.2016.

Pyżalski J. (2017), Małe dzieci w świecie technologii informacyjno-komunikacyjnych - pomiędzy utopijnymi szansami a przesadzonymi zagrożeniami. Łódź, Wydawnictwo „Eter”.

Säljö R. (2010), Digital tools and challenges to institutional traditions of learning: technologies, social memory and the performative nature of learning. „Journal of Computer Assisted Learning", 26.

Wrońska M. (2017), Technologie informacyjne w edukacji - stan obecny i perspektywy ich zastosowania. „Lubelski Rocznik Pedagogiczny”, 36(4). 